\title{
Effects of Regular Exercise and L-Arginine Intake on Abdominal Fat, GH/lGF-1 Axis, and Circulating Inflammatory Markers in the High Fat Diet-Induced Obese Aged Rat
}

Sok Park', Ki Woon Sung², Jin Lee ${ }^{3}$, Cheon Ho Lee', Young Jun Lee ${ }^{5}$, Young June Yoo ${ }^{6}$, Kyoung Shil Park', Byung Jin Min', Yong Sub Shin ${ }^{8}$, Jung Suk Kim ${ }^{9}$ and Hun Jung ${ }^{9}$ *

${ }^{1}$ Division of Sports industry \& Science, Mokwon University, Daejeon 302-729, Korea

${ }^{2}$ Department of Physical education, Sejong University, Seoul 143-747, Korea

${ }^{3}$ Department of Anatomy and Cell Bidogy, Collage of Medicine, Hanyang University, Seoul 143-791, Korea

${ }^{4}$ Department of Physical education, Continuing Education Center, Konkuk University, Seaul 143-701, Korea

${ }^{5}$ Department of Sports for All, Collage of Humanities, Soongsil University, Seoul 156-743, Korea

${ }^{6}$ Department of modeling, Collage of Performance Arts, Dongduk Women's University, Seoul 136-714, Korea

${ }^{7}$ DMajor of Leisure \& Sport Studies, College of Physical Sciences, Kyonggi University, Suwon 443-760, Korea

${ }^{8}$ Department of Combative Martial Arts Training, College of Martial Arts, Yongin University, Yongin 449-714, Korea

${ }^{9}$ Department of Judo, College of Martial Arts, Yongin University, Yongin 449-714, Korea

Received January 5, 2012 /Revised March 26, 2012 /Accepted April 4, 2012

\begin{abstract}
The purpose of this study was to investigate the effect of exercise and/or L-arginine on abdominal fat, IGF-1 on GH/IGF-1 axis, fibrinogen, and PAI-1 in aged and obese rats. Male Sprague-Dawley rats were treated with a D-galactose aging inducing agent $(50 \mathrm{mg} / \mathrm{kg})$ given intraperitoneally for 12 weeks. Thirty-two male Sprague-Dawley rats were treated and divided into four groups: aging-high fat diet group $(\mathrm{AG}+\mathrm{HF}), \mathrm{AG}+\mathrm{HF}$ with L-arginine intake group $(\mathrm{AG}+\mathrm{LA}), \mathrm{AG}+\mathrm{HF}$ with exercise group $(A G+E X)$, and $A G+E X$ with L-arginine intake group (AG+LA+EX). The experimental rats underwent treadmill training (60 min/day, 6 days/week at $0 \%$ gradient) for 12 weeks. L-arginine was given orally $(150 \mathrm{mg} / \mathrm{kg} /$ day) for 12 weeks. After the experiment, blood was collected from the left ventricle and abdominal fat was extracted. The results showed that GH was significantly increased in AG+EX and $A G+A L+E X$. IGF-1 was significantly increased in both the $A G+A L+E X$ and $A G+E X$ group $(p<0.05)$, while fibrinogen and PAI-1 were not significantly different among the groups. Abdominal fat was significantly decreased in the AG+LA, AG+EX, and AG+LA+EX groups $(p<0.05)$ compared with the AG+HF group. In conclusion, this study suggests that exercise alone or L-arginine alone or a combination not only increases the GH and IGF-1 concentration, but also decreases the abdominal fat mass.
\end{abstract}

Key words : L-arginine, Growth hormone (GH), Insulin-like growth factor-1 (IGF- I), fibrinogen, Exercise, Plasminogen activator inhibitor-1 (PAI-1)

\section{서 론}

노인들의 기대수명 증가는 고령화 사회를 만들었지만 이 들의 건강수명은 정체되면서[30] 낮아진 삶의 질과 노인성질 병에 따른 의료비지출은 피할 수 없는 현상이 되었다. 최근 노인들의 건강유지 및 질병예방에 대한 관심들이 고조되고 있는 가운데 노인성질병치료 및 예방법은 현대를 살아가는 모든 이들에게 필요한 대응책으로 이에 따른 연구들이 요구 된다.

먼저 노화가 되면 대표적인 신체변화는 체구성의 변화이 다. 다시 말해 노인의 근육 총 단면적이 20대 연령에 비해 약

*Corresponding author

Tel : +82-31-8020-2620, Fax : +82-31-8020-2882

E-mail : sundance02@naver.com
$40 \%$ 가량 감소하고[14], 이들의 체지방율은 10 년마다 약 $7.5 \%$ 씩 서서히 증가[20]를 하여 노인성비만을 만든다. 노인 성비만의 주요원인은 노화에 따른 근육 내 포도당 이용률 감 소로 에너지 대사량을 떨어뜨렸기 때문에 체내에서 지방축 적이 증가된 것이며, 이러한 과정에서 지방 조직의 변형과 분배에 이상을 초래[26]하여 복부 측 지방 재분배 현상으로 $[5,18]$ 지방이 축적되어 비만이 된다. 노인성비만이 되면 인 슐린 저항성, 당뇨 등의 합병증을 동반할 뿐만 아니라 혈중 지질의 변화로 동맥경화를 비롯하여 심혈관 질환과 같은 발 병률을 증가시켜 노인들의 수명연장에 치명적인 위험인자로 작용할 수 있다[17].

노화에 따른 또 다른 변화는 testosterone, dehydroepiandrosterone, growth hormone $(\mathrm{GH})$ 과 같은 호르몬 감소이다 [25,29]. $\mathrm{GH}$ 은 191 개의 아미노산으로 이루어진 single-chain 
polypeptide로서 주로 뇌하수체 전엽의 somatotroph에서 생 산하거나 분비를 하며[12], GH-releasing hormone (GHRH)에 의해 분비를 자극 받아 시상하부에서 분비되는 somatostatin 에 의해 분비가 억제되어 Insulin-like growth factor I (IGFI)의 분비를 조절하는 호르몬으로 알려져 있다[40]. 혈중 $\mathrm{GH}$ 의 효과는 주로 간에서 합성된 IGF- I 에 의해 매개를 하며[37], IGF binding protein (IGFBP)과 결합하여 순환을 담당한다[4]. $\mathrm{GH} / \mathrm{IGF}-\mathrm{I}$ axis는 주로 성장, 발달[36], 근육의 크기, 그리고 근력을 증강 $[8,9]$ 시킬 뿐만 아니라 체내 지방을 분해하는 탁월 한 효과가 있다고 알려지면서 비만치료에 사용하고 있다 [16,32]. GH/IGF- I axis의 조절은 뇌하수체와 시상하부 그리 고 간의 통합적인 반응에 의해서 일어나며 노화가 진행되는 과정에서 이에 기여하는 몇몇 요인들에 변화가 일어난다[37]. 최근 Ryall 등[34]이 보고한 바에 의하면, 노인에게서의 $\mathrm{GH}$ 일일 분비량은 젊은 성인에 비해 5-20배 가량 낮게 분비를 한 다고 하였고, Papadakis 등[31]은 56명의 노인 남성을 대상으 로 6 개월간 $\mathrm{GH}$ 를 투여한 결과 체지방량이 $13.1 \%$ 줄었다는 연구 결과를 밝힘으로써 GH/IGF- I axis를 활성화가 비만개 선 효과를 제공하고 있음을 입증시켰다. 그러나 이 요법은 말 초조직의 부종과 관절통 같은 부작용 등이 나타났으며 이들 호르몬투여방법에 대한 불신이 고조되면서 식이요법과 운동 요법과 같은 비만치료예방에 관심을 갖는 노인들이 급증하고 있다.

그 중 비 약물요법인 운동은 비만과 심혈관 질환을 개선시 킬 뿐만 아니라 GH/IGF- I axis를 향상시키는 것으로 알려져 있다[45]. 또한 운동이 cholinergic tone을 높여[24] 시상하부에 서 somatostatin의 분비를 억제시키고, GHRH에 대한 민감도 를 높여[7] 노화로 약해진 신체능력을 증진시킬 수 있다.

한편 L-arginine은 체내에서 합성되는 준 필수 아미노산으 로써 몇몇 병리적 상황에 처할 경우 체내 공급량이 부족해진 다고 보고되고 있으며[42], 기능으로는 nitric oxide (NO), creatine, ammonia, urea와 $\mathrm{GH}$ 를 만드는 효과를 가지고 있다 [2,35]. 이러한 이유로 몇몇 연구자들은 L-arginine섭취가 고혈 압을 포함한 심혈관 질환에서도 개선효과를 보여줌으로써 새 로운 치료법으로 도입하고 있다.

지금까지 L-arginine에 관한 대부분의 연구들은 ergogenic effect와 비만, 당뇨 등과 같은 만성 질환자를 대상으로 진행되 어 왔다 [44,45]. 특히 L-arginine의 단독 처치만으로도 $\mathrm{GH}$ 의 반응은 2배 가량 증가 시킬 수 있는[11] 강력한 항 노화물질임 에도 불구하고 L-arginine에 대한 기전규명은 주로 $\mathrm{NO}$ 의 생 성을 촉진하여 혈관노화 과정을 지연시킨다는 연구로 국한되 어 있다. 더욱이 노화비만이 대사증후군을 유발하는 주요한 요인으로 작용한다는 점에서 볼 때 운동과 L-arginine의 복합 처치에 따른 $\mathrm{GH}$ 의 변화가 노화비만예방 및 효과에 대한 연구 결과는 의미 있는 연구라 사료된다. 따라서 본 연구의 목적은 운동과 L-arginine의 복합처치에 대한 효과를 규명하고자 하
였으며, 특히 노화와 관련된GH/IGF- I axis와 혈관 염증인자 들의 상호 작용을 조사해서 노화와 관련된 비만에서 운동과 L-arginine의 효과를 제시하고자 한다.

\section{재료 및 방법}

\section{연구대상}

본 연구의 실험동물은 (주)샘타코로 부터 6주령 SpragueDawley 계의 수컷 흰쥐 50 마리를 분양 받아 1 주간의 환경적응 을 거친 뒤 무선배정을 통하여 본 실험을 하였다. 실험집단은 총 4 그룹으로 분류하였으며, 한 집단에 8 마리씩 각각 다음과 같이 분류하였다.

(1) 노화유도-고지방 사료 집단(aging-high fat diet; AG+ $\mathrm{HF})$, (2) 노화유도-고지방 사료+L-arginine 투여 집단 $(\mathrm{AG}+\mathrm{LA})$, 노화유도-고지방사료+운동집단( $\mathrm{AG}+\mathrm{EX})$, (3) 노화 유도-고지방사료+L-arginine+운동집단( $\mathrm{AG}+\mathrm{LA}+\mathrm{EX})$ 으로 실 험기간 동안 식이와 물은 자유롭게 섭취하도록 하였다. 사육 실의 온도 $\left(22 \pm 1^{\circ} \mathrm{C}\right), \quad$ 습도 $(60 \pm 3 \%) \quad$ 그리고 조명(12시간 light/dark cycle)은 자동조절에 의해 운영되었다.

\section{고지방식이 섭취}

본 연구를 위한 식이섭취는 지방이 전체 칼로리의 $60 \%$ 를 차지하는 고지방식이사료를 섭취하였다. 각각의 실험동물은 고지방 식이로 사육하기 전 1 주일간 고형배합사료로 환경에 적응시킨 후 실험용 고지방 식이사료 Table 1로 12주간 사육하 였다.

\section{노화유발}

노화유도는 Lei 등[27]의 방법을 인용하였으며, 산화적 스트 레스생성증가로 노화를 유발하기 위해 D-galactose (D-gal)

Table 1. High fat diet composition

\begin{tabular}{lc}
\hline Ingredient & Content $(\mathrm{g} / \mathrm{kg})$ \\
\hline Casein & 200 \\
L-Cystine & 3 \\
Maltodextrin & 125 \\
Sucrose & 68.8 \\
Cellulose & 50 \\
Soybean Oil & 25 \\
Lard & 245 \\
Mineral Mix & 10 \\
DiCalcium & 13 \\
Phosphate & 5.5 \\
Calcium & 16.5 \\
Carbonate & 10 \\
Potassium Citrate & 2 \\
Vitamin Mix & 10 \\
Choline Bitartrate & 2 \\
\hline
\end{tabular}


(Sigma, USA)를 생리식염수에 녹여 $50 \mathrm{mg} / \mathrm{kg}$ 의 용량을 복강 내 투여하였다. Con그룹은 동일한 량의 생리식염수를 투여하 였으며, 1일 1회, 총 12주간 투여하였다.

\section{L-arginine 투여}

L-arginine (No. W381918; Sigma, USA) 투여 방법은 Adriào 등[2]의 방법을 응용하였으며, 투여방법은 L-arginine (Sigma, USA)을 생리식염수에 혼합하여 체중 $\mathrm{kg}$ 당 $150 \mathrm{mg}$ 을 1 일 1 회 일정한 시간대와 순서로 12 주간 경구 투여하였고, $\mathrm{HF}$ 집단과 EX 집단에게는 동일한 량의 생리식염수를 같은 방법 으로 경구 투여하였다.

\section{운동방법}

운동 처치는 Chang 등[8]의 방법을 인용하였으며, 설치류 전용 트레드밀에서 경사도 $0 \%$ 에서 운동 적응기 1 주를 거친 후 주 6 회 $20 \mathrm{~m} / \mathrm{min}$ 속도에서 60 분간 총 12 주간 실시하였다.

\section{혈액채취 및 분석}

12 주간의 실험을 마친 실험 쥐들은 종료 2시간 후 pentobarbital sodium $(50 \mathrm{mg} / \mathrm{kg})$ 을 복강 내로 투여하여 마취시킨 뒤 개흥하여 좌심실로부터 1 회용 주사기로 $6 \mathrm{ml}$ 의 혈액을 채 취하였다. 채취한 혈액은 원심분리기(KM 70 Germany)로 10 분간 3,000 rpm에서 원심 분리하여 혈청을 획득한 뒤 분석 시까지 $-70^{\circ} \mathrm{C}$ 에서 보관하였다.

GH, IGF- I , IGFBP, somatostatin분석은 면역방사측정법 (Immuno Radiometric Assay)을 이용하였다. 각각의 혈청 농 도는 측정용 RIA kit (Daiichi, Japan)를 사용하여 y counter COBRA- $\Pi$ (PACKARD, USA)로 측정하였고, 혈중 혈관염증 관련인자로는 fibrinogen은 PT-fibrinogen (삼일, 한국) 시약을 이용하여 Photo-optical Coagulation System 방법으로 측정하 였다. 또한 plasminogen activator inhibitor-1 (PAI-1) 농도는 효소면역측정법(enzyme immuno-assay) kit (Biopool Unea, Sweden)을 이용하여 측정하였다.

\section{복부지방량 분석}

실험동물을 pentobarbital sodium $(50 \mathrm{mg} / \mathrm{kg})$ 로 마취시킨 후 복부를 절개하여 복부지방 조직을 절취하여 전자저울(CAS CUX 220H, Japan)을 사용하여 측정하였다.

\section{통계방법}

모든 실험결과는 평균과 표준편차를 산출하였으며, 통계프 로그램 SPSS Ver. 17.0을 이용하여 유의성을 검정하였다. 각각 의 변인에 대한 처치 그룹간의 차이는 일원변량분석(one-way ANOVA)을 실시하였으며, 사후 검증으로 Tukey's multiple range test를 이용하였다. 각 분석 시 유의수준은 $p<0.05$ 로 설 정하였다.

\section{결 과}

\section{복부지방량의 변화}

노화 및 비만 유발 쥐에게서 12 주간 규칙적인 트레드밀 운 동과 L-arginine을 처치한 결과 집단 간 복부지방량의 변화는 Table 2, Fig. 1에서와 같다. 복부지방량 무게의 변화는 $\mathrm{AG}+\mathrm{HF}$ 집단과 비교하였을 때 모든 집단에서 유의하게 감소 하였다( $p<0.001)$

\section{혈중 GH//GF- I axis 관련 변인들의 변화}

고지방 사료 및 D-galactose로 인해 비만과 노화가 유발 된 흰쥐에게서 12 주간의 L-arginine 투여와 트레드밀 운동 이 미치는 영향을 알아보기 위하여 GH/IGF-I axis 관련 변인들의 변화를 측정한 결과는 Table 3, Fig. 2, 3와 같다. 뇌하수체로부터 분비되어 $\mathrm{GH}$ 의 분비를 억제하는 somatostatin의 혈중 농도는 모든 집단에서 유의한 차이가 나타나지

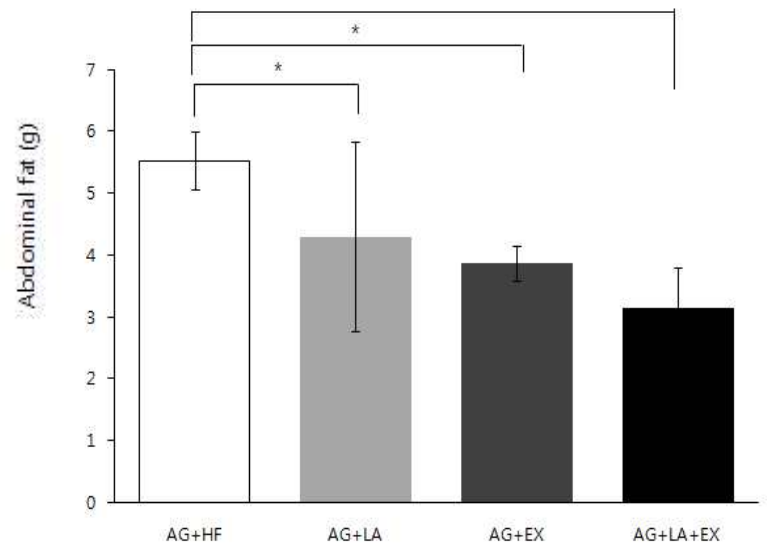

Fig. 1. Differences in the concentrations of abdominal fat mass.

Table 2. Abdominal fat mass

\begin{tabular}{|c|c|c|c|c|c|}
\hline & & & $\mathrm{F}$ & Sig. & Post-hoc \\
\hline \multirow{4}{*}{$\begin{array}{l}\text { Abdominal fat } \\
(\mathrm{g})\end{array}$} & $\mathrm{AG}+\mathrm{HF}$ & $5.53 \pm 0.46$ & \multirow{4}{*}{24.39} & \multirow{4}{*}{0.001} & $\mathrm{AG}+\mathrm{HF}-\mathrm{AG}+\mathrm{E} X^{*}$ \\
\hline & $\mathrm{AG}+\mathrm{LA}$ & $4.30 \pm 1.53$ & & & $\mathrm{AG}+\mathrm{HF}-\mathrm{AG}+\mathrm{LA} *$ \\
\hline & $\mathrm{AG}+\mathrm{EX}$ & $3.87 \pm 0.29$ & & & $\mathrm{AG}+\mathrm{HF}-\mathrm{AG}+\mathrm{LA}+\mathrm{EX}^{*}$ \\
\hline & $A G+L A+E X$ & $3.15 \pm 0.64$ & & & AG+LA-AGLA+EX* \\
\hline
\end{tabular}


Table 3. GH-related factors

\begin{tabular}{|c|c|c|c|c|c|}
\hline & & & $\mathrm{F}$ & Sig. & Post-hoc \\
\hline \multirow{4}{*}{$\begin{array}{c}\mathrm{GH} \\
(\mathrm{ng} / \mathrm{dl})\end{array}$} & $\mathrm{AG}+\mathrm{HF}$ & $0.17 \pm 0.08$ & \multirow{4}{*}{4.900} & \multirow{4}{*}{$0.010^{*}$} & \multirow{4}{*}{$\begin{array}{l}A G+H F-A G+E X^{*} \\
A G+H F-A G+L A+E X^{*}\end{array}$} \\
\hline & $\mathrm{AG}+\mathrm{LA}$ & $0.26 \pm 0.05$ & & & \\
\hline & $\mathrm{AG}+\mathrm{EX}$ & $0.30 \pm 0.08$ & & & \\
\hline & $\mathrm{AG}-\mathrm{LA}+\mathrm{EX}$ & $0.32 \pm 0.09$ & & & \\
\hline \multirow{4}{*}{$\begin{array}{l}\text { IGF- I } \\
(\mathrm{ng} / \mathrm{dl})\end{array}$} & $\mathrm{AG}+\mathrm{HF}$ & $774.17 \pm 105.69$ & \multirow{4}{*}{11.040} & \multirow{4}{*}{$0.001^{*}$} & $A G+H F-A G+E X^{*}$ \\
\hline & $\mathrm{AG}+\mathrm{LA}$ & $948.83 \pm 107.57$ & & & $A G+H F-A G+L A+E X^{*}$ \\
\hline & $\mathrm{AG}+\mathrm{EX}$ & $1170.33 \pm 138.81$ & & & $A G+E X-A G+L A^{*}$ \\
\hline & $A G+L A+E X$ & $967.25 \pm 123.16$ & & & $A G+E X-A G+L A+E X^{*}$ \\
\hline \multirow{4}{*}{$\begin{array}{l}\text { IGFBP } \\
(\mathrm{ng} / \mathrm{dl})\end{array}$} & $\mathrm{AG}+\mathrm{HF}$ & $63.00 \pm 19.29$ & \multirow{4}{*}{0.060} & \multirow{4}{*}{0.980} & \\
\hline & $\mathrm{AG}+\mathrm{LA}$ & $64.67 \pm 23.81$ & & & \\
\hline & $A G+E X$ & $68.00 \pm 18.66$ & & & \\
\hline & $\mathrm{AG}+\mathrm{LA}+\mathrm{EX}$ & $66.50 \pm 24.46$ & & & \\
\hline \multirow{4}{*}{$\begin{array}{l}\text { Somatostatin } \\
\qquad(\mathrm{pg} / \mathrm{dl})\end{array}$} & $\mathrm{AG}+\mathrm{HF}$ & $4069.50 \pm 3490.91$ & \multirow{4}{*}{0.353} & \multirow{4}{*}{0.787} & \\
\hline & $\mathrm{AG}+\mathrm{LA}$ & $4534.00 \pm 2646.12$ & & & \\
\hline & $A G+E X$ & $4386.00 \pm 3254.93$ & & & \\
\hline & $\mathrm{AG}+\mathrm{LA}+\mathrm{EX}$ & $2975.50 \pm 1975.84$ & & & \\
\hline
\end{tabular}

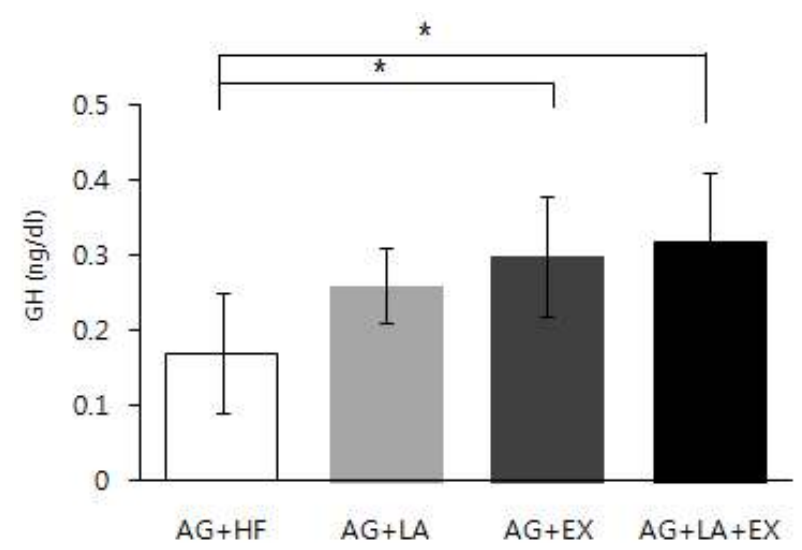

Fig. 2. Differences in the concentrations of GH.

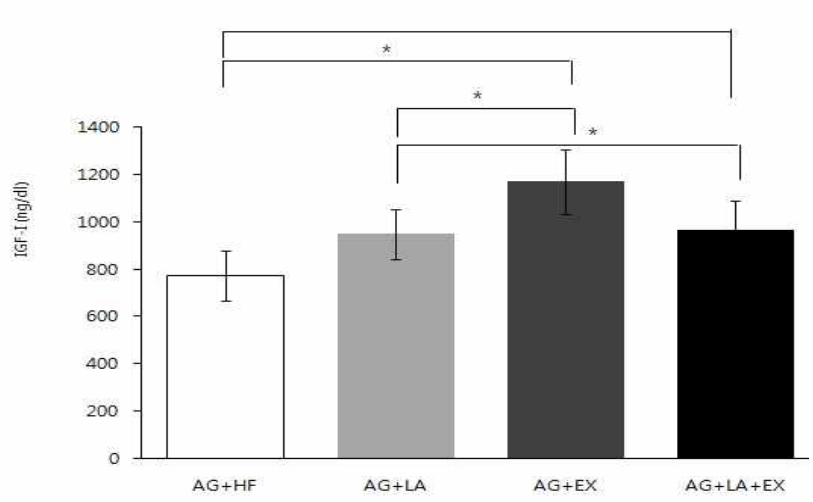

Fig. 3. Differences in the concentrations of IGF-1.

않았다. 반면 노화가 진행됨에 따라 그 분비가 감소하는 $\mathrm{GH}$ 의 혈중 농도는 트레드밀 운동을 실시한 $\mathrm{AG}+\mathrm{EX}$ 집단과
$\mathrm{AG}+\mathrm{LA}+\mathrm{EX}$ 집단에서 $\mathrm{AG}+\mathrm{HF}$ 집단에 비해 증가된 것으로 유의한 차이가 있는 것으로 나타났다 $(p<0.01) . \mathrm{GH}$ 에 의해 분비가 자극되어지는 IGF- I 의 혈중 농도는 $\mathrm{AG}+\mathrm{HF}$ 집단에 비해 $\mathrm{AG}+\mathrm{EX}$ 와 $\mathrm{AG}+\mathrm{LA}+\mathrm{EX}$ 그룹에서 각각 증가를 하였으 며 유의한 차이가 있는 것으로 나타났다 $(p<0.001)$. 혈중에서 IGF- I 을 수송하는 역할을 하는 IGFBP의 농도는 AG+HF 집단과 비교하여 모든 처치 집단 간에 유의한 차이가 없는 것으로 나타났다(Table 3).

\section{혈중 Fibrinogen, PAl-1의 변화}

12주간의 L-arginine 및 트레드밀 운동처치에 따른 혈관 내 염증인자인 fibrinogen과 PAI-1를 측정한 결과는 Table 4와 같다. 두 염증인자 모두 트레드밀 운동과 L-arginine의 단독 및 복합처치 집단 모두에서 유의한 차이가 없는 것으로 나타 났다.

\section{고 찰}

노화에 따른 비만은 다양한 대사증후와 관련되어 있으며, 그 중 노화과정에서 발현하는 $\mathrm{GH} / \mathrm{IGF}-\mathrm{I}$ axis의 억제가 지방 축적 $[33,37]$ 에 영향을 주는지 살펴보기 위하여 12 주간 D-gal투 여와 고지방식이를 하였다.

흔히 노화는 세포 내 자유유리기(free radical)를 통해 지질, 단백질, 그리고 DNA 손상으로 나타나는 것[39]처럼 본 연구 에서는 노화를 유도하기 위해 장기간 D-gal을 투여하였다. 이 는 D-gal의 투여로 조직 내 축적되면 세포 내에서는 산화적 스트레스를 높여 더욱 빠른 노화현상이 나타나기 때문이다 [38]. 그러므로 본 실험에서 이용된 모든 그룹들에게 D-gal을 
Table 4. Vascular inflammation factors

\begin{tabular}{|c|c|c|c|c|c|}
\hline & & & $\mathrm{F}$ & Sig. & Post-hoc \\
\hline \multirow{4}{*}{$\begin{array}{c}\text { Fibtinogen } \\
\text { (mg/dl) }\end{array}$} & $\mathrm{AG}+\mathrm{HF}$ & $266.33 \pm 69.61$ & \multirow{4}{*}{0.804} & \multirow{4}{*}{0.506} & \\
\hline & $\mathrm{AG}+\mathrm{LA}$ & $202.67 \pm 131.66$ & & & \\
\hline & $\mathrm{AG}+\mathrm{EX}$ & $199.50 \pm 129.58$ & & & \\
\hline & $\mathrm{AG}+\mathrm{LA}+\mathrm{EX}$ & $166.67 \pm 113.40$ & & & \\
\hline \multirow{4}{*}{$\begin{array}{l}\text { PAI-1 } \\
\text { (ng/dl) }\end{array}$} & $\mathrm{AG}+\mathrm{HF}$ & $50.90 \pm 22.49$ & \multirow{4}{*}{0.093} & \multirow{4}{*}{0.963} & \\
\hline & $\mathrm{AG}+\mathrm{LA}$ & $45.88 \pm 15.63$ & & & \\
\hline & $\mathrm{AG}+\mathrm{EX}$ & $47.17 \pm 32.11$ & & & \\
\hline & $\mathrm{AG}+\mathrm{LA}+\mathrm{EX}$ & $44.17 \pm 18.13$ & & & \\
\hline
\end{tabular}

투여하였고, 노화유도와 함께 고지방식이로 증가된 복부지방 량의 변화와 혈중 GH, IGF-I, IGFBP, somatostatin, fibrinogen, 그리고 PAI-1의 농도를 측정하였다. 그 결과 AG-HF그 룹의 복부지방량의 무게는 다른 3그룹들에 비해 유의하게 증 가하였지만, 혈중 GH, IGF-I 의 수치는 뚜렷하게 감소된 것으 로 나타났다. 이러한 결과는 고지방식이로 지방이 증가된 것 으로 사료되며, 유도된 노화는 생리학적 변화 등으로 체내 항 상성을 유지하는 능력이 저하되었기 때문에[1] GH, IGF- I 가 억제되면서 지방분해의 활성이 저하됨에 따라 복부지방량은 더욱 축적되어 증가된 것으로 사료된다[6]. 게다가 IGH-1의 생성과 분비는 $\mathrm{GH}$ 의 분비로 영향을 받아 체지방과 복강 내 지방의 양을 조절을 하기 때문에 $[4,37]$ 이들의 발현 억제는 복 부지방량을 더욱 증가시킨 것이라 할 수 있다.

본 연구에서는 염증관련인자인 fibrinogen, PAI-1의 수치를 알아보았다. 그 결과 $\mathrm{AG}+\mathrm{HF}$ 그룹이 다른 그룹들에 비해 높은 것으로 나타났지만 유의한 차이는 보이지 않았다. 이는 D-gal 의 투여로 유도된 산화적 스트레스가 세포의 기능을 떨어뜨리 고 손상시켜 더 높은 염증반응을 유도[10]한 것으로 사료된다. 뿐만 아니라 fibrinogen과 PAI-1은 혈전을 형성하는 인자로 알려져 있기 때문에 이들의 발현증가는 혈관 내 혈전형성의 증가와 더불어 동맥경화와 혈전관련 질환 등을 유발시킨다. 다시 말해, 노화비만에 따른 지방의 증가 및 혈전형성은 매우 밀접한 관계가 있기 때문에 주로 fibrinogen과 PAI-1의 발현 증가는 혈전증 유발로 심혈관질환에 매우 치명적인 결과를 제공할 수 있을 것으로 사료된다[40].

그러므로 유도된 노화비만에 따른 복부지방량 증가와 혈중 $\mathrm{GH}, \mathrm{IGF}-\mathrm{I}$ 감소는 지방대사장애와 관련된 노인성질환에 노 출될 수 있음을 예측할 수 있다.

노인성비만과 관련되어 지방조직 감소와 혈중 $\mathrm{GH}, \mathrm{IGF}-\mathrm{I}$, IGFBP, somatostatin의 증가 및 fibrinogen, PAI-1의 억제가 요구되는 시점에서 규칙적인 트레드밀 운동과 L-arginine의 투여는 각각 비만 및 노화예방에 있어서 그 효과가 입증되었 음에도 불구하고 혈중 GH, IGF- I, IGFBP, somatostatin, fibrinogen, PAI-1농도차이에 대한 명확한 연구결과는 여전히 부족하다. 따라서 본 연구는 D-gal로 노화유도흰쥐를 대상으 로 12 주간 고지방식이와 트레드밀 운동을 통해 GH, IGF- I,
IGFBP, somatostatin, fibrinogen, PAI-1농도차이를 알아보고 자 하였다. 그 결과 $\mathrm{AG}+\mathrm{LA}, \mathrm{AG}+\mathrm{EX}$ 그리고 $\mathrm{AG}+\mathrm{LA}+\mathrm{EX}$ 그룹 에서의 복부지방량은 $\mathrm{AG}+\mathrm{HF}$ 그룹에 비해 유의하게 감소되었 고, $\mathrm{GH}, \mathrm{IGF}-\mathrm{I}$ 수치는 $\mathrm{AG}+\mathrm{HF}$ 그룹에 비해 유의하게 증가된 것으로 나타났다. 이러한 결과는 지속적으로 트레드밀 운동을 수행하여 $\mathrm{GH}$ 수치를 증가시켰다고 보고한 선행연구들[21,45] 과 일치된 결과이며, 운동으로 증가된 $\mathrm{GH}$ 가 복부 지방 조직의 지방분해작용을 활성 시켜 복부지방량을 감소[15]시킨 것이라 할 수 있다. L-arginine 투여 역시 $\mathrm{GH}$ 의 분비를 자극하여 체중 을 조절하고 신체조성에 긍정적인 효과를 가지고 있음을 Walczewsk \& Trzewikoska 등[42]이 입증하였다. 또한 장기간 L-arginine투여가 인슐린 민감성 조직들을 지방대사에 관련된 주요 효소들을 활성 시킴으로써 지방을 분해하거나 새로운 지방세포 생성들을 억제시킨 것[23]으로 사료된다. 그러므로 본 연구에서는 12 주간의 L-arginine투여와 트레드밀 운동 그 리고 복합처지집단에서 대조집단과 비교하여 $\mathrm{GH}$ 의 분비를 높여 지방의 증가를 감소시키는 효과를 보여주었다. 하지만 트레드밀 운동과 달리 $\mathrm{GH}$ 의 농도는 유의한 차이를 보이지 않았는데 이는 운동을 단독 처치한 그룹에서 $\mathrm{GH}$ 의 농도가 5 배 증가한 반면 L-arginine을 단독 처치한 그룹에서는 약 2 배 의 증가를 보고한 Collier 등[11]의 연구와 일부 일치하는 결과 로서 L-arginine의 투여가 운동에 비해 생리적 자극의 크기가 적었던 것으로 사료된다.

$\mathrm{GH}$ 는 인슐린과 길항작용을 하여 지방분해를 활성화시키 며, 지방세포에서는 성장호르몬에 대한 수용체들이 이들 호르 몬에 의해 지방분해를 하기 때문에 지방량을 감소시킨다. L-arginine은 $\mathrm{GH}$ 을 억제시키는 somatostatin의 분비를 막아 $\mathrm{GH}$ 의 분비를 증가시킨다고 알려져 있다[28]. 그러나 본 연구 에서는 L-arginine투여와 트레드밀 운동은 somatostatin의 분 비를 억제시키지 못하였다. 이는 GH와 IGF- I 의 농도가 주로 시상하부에서 분비되는 somatostatin을 억제함에 따라 분비를 증가시킨다는 기존 연구 결과들과 상이한 결과로서 GH, IGF$\mathrm{I}$ 을 조절하는 또 다른 상위 기전이 작용했을 것으로 사료된 다. 이에 대해 de Vries 등[13]은 운동에 의한 $\mathrm{GH}$ 의 증가는 뇌하수체에서 somatostatin의 분비를 억제시킨 것이 아니라 $\mathrm{GHRH}$ 와 ghrelin의 작용 때문에 영향을 미친 것으로 보고하 
였다. 또한 운동을 통해 somatostatin 농도가 감소하기 위해서 는 최대하 강도의 운동을 통해 cholinergic tone의 변화[22]가 우선적으로 일어나야 되는데 본 연구에서 실시한 트레드밀 운동의 강도가 그에 미치지 못했던 것으로 사료된다. 또한 L-arginine의 투여로 somatostatin의 농도에 유의한 변화가 관 찰되지 않은 점과 L-arginine이 $\mathrm{GH}$ 를 증가시키는 기전[19]을 고려하였을 때 본 연구결과 12 주간 투여된 L-arginine의 생리 적 자극이 적었던 것으로 사료된다. 이상의 결과들을 종합해 볼 때, 12 주간의 트레드밀 운동은 GH, IGF- I 을 증가시키고 복부지방량을 감소시킬 수 있을 것으로 여겨지며, L-arginine 과의 장기간 복합처치는 더욱 효과적일 것으로 사료된다.

노화유도비만에서 증가된 염증인자들의 활동억제가 요구 되는 시점에서 본 연구는 L-arginine투여와 트레드밀 운동으 로 염증인자인 fibrinogen와 PAI-1농도차이에 대해 규명하고 자 하였다. 그 결과 $\mathrm{AG}+\mathrm{LA}, \mathrm{AG}+\mathrm{EX}$ 그리고 $\mathrm{AG}+\mathrm{LA}+\mathrm{EX}$ 그룹 에서의 fibrinogen와 PAI-1수치는 AG+HF그룹에 비해 낮은 것으로 나타났지만 유의한 차이는 보이지 않았다. 이는 운동 이 혈소판의 활동을 감소시키고, 혈소판의 응고 및 유착을 억 제하였기 때문이며, 혈관 주변에 있는 염증반응과 혈전 생성 을 막아 혈관의 기능을 더욱 활성 시키기는 것으로 알려진 것[36]처럼 본 연구에서도 염증관련인자들의 활동에 긍정적으 로 작용한 것으로 사료된다. 게다가 L-arginine투여가 혈관확 장인자들의 발현을 증가 및 콜레스테롤의 수치를 감소[3,35]시 켜 염증인자들의 활동을 억제시켰을 것으로 추측된다.

이상의 결과를 종합해 볼 때, 노화유도비만에 있어 L-arginine 과 규칙적인 운동은 복부지방량 감소와 성장인자로 알려 진 GH, IGF-I 수치 증가로 노화비만으로부터 치료예방효과 가 있을 것으로 사료된다. 더욱이 노인성비만에 있어서 치료 물질로 대체할 L-arginine의 역할과 운동의 병행은 노인성비 만에 대해 항 비만효과와 성장호르몬분비능력에 유익한 효과 를 제공할 수 있을 것으로 사료된다.

\section{감사의 글}

연구는 2010년도 용인대학교 학술연구비 지원에 의해 수행 되었습니다.

\section{References}

1. Adelman, R, C., Britton, G. W. and Rotenberg, S. 1987. Endocrine regulation of gene activity in aging animals of different genotypes. New York: Alan R. Liss, 355.

2. Adriäo, M., Chrisman, C. J., Bielavsky, M., Olinte, S. C., Shiraishi, E. M. and Nunes, M. T. 2004. Arginine increases growth hormone gene expression in rat pituitary and GH3 cells. Neuroendocrinology 79, 26-33.

3. Alba-Roth, J., Muller, O. A., Schopohl, J. and von Werder,
K. 1988. Arginine stimulates growth hormone secretion by suppressing endogenous somatostatin secretion. J. Clin. Endocrinol. Metab. 67, 1186-1189.

4. Ballard, J., Baxter, R., Binoux, M., Clemmons, D., Drop, S., Hall, K., Hintz, R., Rechler, M., Rutanen, E. and Schwander, J. 1989. On the nomenclature of the IGF binding proteins. Acta. Endocrinol. (Copenh) 121, 751-752.

5. Borkan, G. A., Hults, D. E., Gerzof, S. G. and Robbins, A. H. 1985. Comparison of body composition in middle-aged and elderly males using computed tomography. Am J. Phys. Anthropol. 66, 289-295.

6. Carroll, P. V., Christ, E. R., Bengtsson, B. A., Carlsson, L., Christiansen, J. S., Clemmons, D, Hintz, R., Ho, K., Laron, Z., Sizonenko, P., Sonksen, P. H., Tanaka, T. and Thorne, M. 1998. Growth hormone deficiency in adulthood and the effects of growth hormone replacement: a review. Growth Hormone Research Society Scientific Committee. J. Clin. Endocrinol. Metab. 83, 382-395.

7. Casanueva, F. F., Villanueva, L., Cabranes, J. A., Cabezas-Cerrato, J. and Fernandez-Cruz, A. 1984. Cholinergic mediation of growth hormone secretion elicited by arginine, clonidine, and physical exercise in man. J. Clin. Endocrinol. Metab. 59, 526-530.

8. Chang, S. P., Chen, Y. H., Chang, W. C., Liu, I. M. and Cheng, J. T. 2004. Increase of anti-oxidation by exercise in the liver of obese Zucker rats. Clin. Exp. Pharmacol. Physiol. 31, 506-511.

9. Chromiak, J. A. and Antonio, J. 2002. Use of amino acids as growth hormone-releasing agents by athletes. Nutrition 18, 657-661.

10. Chung, H. Y., Sung, B., Jung, K. J., Zou, Y. and Yu, B. P. 2006. The molecular inflammatory process in aging. Antioxid Redox. Signal. 8, 572-581.

11. Collier, S. R., Collins, E. and Kanaley, J. A. 2006. Oral arginine attenuates the growth hormone response to resistance exercise. J. Appl. Physiol. 101, 848-852.

12. Davidson, M. B. 1987. Effect of growth hormone on carbohydrate and lipid metabolism. Endocr. Rev. 8, 115-131.

13. de Vries, W. R., Abdesselam, S. A., Schers, T. J., Maas, H. C., Osman-Dualeh, M., Maitimu, I. and Koppeschaar, H. P. 2002. Complete inhibition of hypothalamic somatostatin activity is only partially responsible for the growth hormone response to strenuous exercise. Metabolism 51, 1093-1096.

14. Doherty, T. J., Vandervoort, A. A. and Brown, W. F. 1993. Effects of ageing on the motor unit: a brief review. Can. J. Appl. Physiol. 18, 331-358.

15. Enevoldsen, L. H., Polak, J., Simonsen, L., Hammer, T., Macdonald, I., Crampes, F., de Gilsezinski, I., stich, V. and Bülow, J. 2007. Post-exercise abdominal, subcutaneous adipose tissue lipolysis in fasting subjects is inhibited by infusion of the somatostatin analogue octreotide. Cin. Physiol. Funct. Imaging 27, 320-326

16. Fineberg, S. E., and Merimee, T. J. 1974. Acute metabolic effects of human growth hormone. Diabetes 23, 499-504.

17. Gabriely, I., Ma, X. H., Yang, X. M., Atzmon, G., Rajala, M. W. and Berg, A. H. 2002. Removal of visceral fat prevents 
insulin resistance and glucose intolerance of aging: an adipokine-mediated process? Diabetes 51, 2951-2958.

18. Gallagher, D., Ruts, E., Visser, M., Heshka, S., Baumgartner, R. N. and Wang, J. 2000. Weight stability masks sarcopenia in elderly men and women. Am J. Physid. Endocrinol. Metab. 279, E366-375.

19. Ghigo, E., Arvat, E., Valente, F., Nicolosi, M., Boffano, G. M. and Procopio, M. 1991. Arginine reinstates the somatotrope responsiveness to intermittent growth hormone-releasing hormone administration in normal adults. Neuroendocrinology 54, 291-294.

20. Hughes, V. A., Frontera, W. R., Roubenoff, R., Evans, W. J. and Singh, M. A. 2002. Longitudinal changes in body composition in older men and women: role of body weight change and physical activity. Am J. Clin. Nutr. 76, 473-481.

21. Irving, B. A., Weltman, J. Y., Patrie, J. T., Davis, C. K., Brock, D. W., Swift, E., Barrett, E. J., Gaesser, G. A. and Weltman, A. 2009. Effects of exercise training intensity on nocturnal growth hormone secretion in obese adults with the metabolic syndrome. J. Clin. Endocrinol. Metab. 94, 1979-1986.

22. Jaffe, C. A., DeMott-Friberg, R. and Barkan, A. L. 1996. Endogenous growth hormone (GH)-releasing hormone is required for $\mathrm{GH}$ responses to pharmacological stimuli. $J$. Clin. Invest, 97, 934-940.

23. Jobgen, W., Meininger, C. J., Jobgen, S. C., Li, P., Lee, M. J., Smith, S. B., Spencer, T. E., Fried, S. K. and Wu, G. 2009. Dietary L-arginine supplementation reduces white fat gain and enhances skeletal muscle and brown fat masses in diet-induced obese rats. J. Nutr. 139, 230-237.

24. Kelijman, M. and Frohman, L. A. 1991. The role of the cholinergic pathway in growth hormone feedback. J. Clin. Endocrinol. Metab. 72, 1081-1087.

25. Lamberts, S. W., van den Beld, A. W. and van der Lely, A. J. 1997. The endocrinology of aging. Science 278, 419-424.

26. Lee, M., Martin, H., Firpo, M. A. and Demerath, E. W. 2011. Inverse association between adiposity and telomere length: The Fels Longitudinal Study. Am J. Hum Biol. 23, 100-106.

27. Lei, M., Hua, X, Xiao, M., Ding, J., Han, Q. and Hu, G. 2008. Impairments of astrocytes are involved in the D-galactose-induced brain aging. Biochem Biophys. Res. Commun. 369, 1082-1087.

28. Lely, A. J. 1999. Growth hormone and ageing. $G H \& I G F$ Res. 9, 117-119.

29. Lunenfeld, B. 2006. Endocrinology of the aging male. Minerva Ginecol. 58, 153-170.

30. Murray, C. J. and Lopez, A. D. 1997. Regional patterns of disability-free life expectancy and disability-adjusted life expectancy: global Burden of Disease Study. Lancet. 349, 1347-1352.

31. Papadakis, M. A., Grady, D., Black, D., Tierney, M. J., Gooding, G. A., Schambelan, M. and Grunfeld, C. 1996. Growth hormone replacement in healthy older men improves body composition but not functional ability. Ann Intern. Med 124, 708-716.

32. Rasmussen, M. H., Hvidberg, A., Juul, A., Main, K. M., Gotfredsen, A., Skakkebaek, N. E., Hilsted, J. and
Skakkebae, N. E. 1995. Massive weight loss restores 24-hour growth hormone release profiles and serum insulin-like growth factor-I levels in obese subjects. J. Clin. Endocrinol. Metab. 80, 1407-1415.

33. Rudling, M., Parini, P. and Angelin, B. 1997. Growth hormone and bile acid synthesis. Key role for the activity of hepatic microsomal cholesterol 7alpha-hydroxylase in the rat. J. Clin. Invest. 99, 2239-2245.

34. Ryall, J. G., Schertzer, J. D. and Lynch, G. S. 2008. Cellular and molecular mechanisms underlying age-related skeletal muscle wasting and weakness. Biogerontology 9, 213-228.

35. Schaefer, A., Piquard, F., Geny, B., Doutreleau, S., Lampert, E., Mettauer, B. and Lonsdorfer, J. 2002. L-arginine reduces exercise-induced increase in plasma lactate and ammonia. Int. J. Sports Med 23, 403-407.

36. Sessa, W. C., Pritchard, K. and Seyei, N. I. 1994. Chronic exercise in dogs increases coronary vascular nitric oxide production and endothelial cell nitric oxide synthase gene expression. Circ. Res. 74, 349-353.

37. Sherlock, M. and Toogood, A. A. 2007. Aging and the growth hormone/insulin like growth factor-I axis. Pituitary 10, 189-203.

38. Song, X., Bao, M., Li, D. and Li, Y. M. 1999. Advanced glycation in D-galactose induced mouse aging model. Mech Aging Dev. 108, 239-251.

39. Tahara, S., Matsuo, M. and Kaneko, T. 2001. Age-related changes in oxidative damage to lipids and DNA in rat skin. Mach Aging Dev. 122, 415-426.

40. Tracy, R. P. and Bovill, E. G. 1992. Thrombosis and cardiovascular risk in the elderly. Arch Pathol. Lab. Med 116, 1307-1312.

41. Trovati, M., Anfossi, G. Massucco, P., Mattiello, L., Costamagna, C., Piretto, V., Mularoni, E., Cavalot, F., Bosia, A. and Ghigo, D. 1997. Insulin stimulates nitric oxide synthesis in human platelets and, through nitric oxide, increases platelet concentrations of both guanosine- $3^{\prime}, 5^{\prime}$-cyclic monophosphate and adenosine-3', 5'-cyclic monophosphate. Diabetes 46, 742-749.

42. Walczewsk, B. and Trzewikoska, M. 1993. Influence of glutamic acid, histidine and arginine on dietary intake. Chemical structure and body mass composition of rats. Rocz. Panstw. Zakl. Hig. 44, 181-189.

43. Wilmore, D. 2004. Enteral and parenteral arginine supplementation to improve medical outcomes in hospitalized patients. J. Nutr. 134, 2863-2867.

44. Woodhouse, L. J., Asa, S. L., Thomas, S. G. and Ezzat, S. 1999. Measures of submaximal aerobic performance evaluate and predict functional response to growth hormone $(\mathrm{GH})$ treatment in GH-deficient adults. J. Clin. Endocrinol. Metab. 84, 4570-4577.

45. Wu, G., Collins, J. K., Perkins-Veazie, P., Siddiq, M., Dolan, K. D., Kelly, K. A., Heaps, C. L. and Meininger, C. J. 2007. Dietary supplementation with watermelon pomace juice enhances arginine availability and ameliorates the metabolic syndrome in Zucker diabetic fatty rats. J. Nutr. 137, 2680-2685. 
46. Zajac, A., Poprzecki, S., Zebrowska, A., Chalimoniuk, M. and Langfort, J. 2010. Arginine and ornithine supplementation increases growth hormone and insulin-like growth factor-1 serum levels after heavy-resistance exercise in strength-trained athletes. J. Strength Cond Res. 24, 10821090 .

초록 : 규칙적인 운동과 L-arginine의 섭취가 고지방식이 유도 비만 노화생쥐의 복부지방량, GH/IGF-1 axis 및 혈관염증지표에 미치는 영향

박석 ${ }^{1} \cdot$ 성기운 $^{2} \cdot$ 이 진 ${ }^{3} \cdot$ 이천호 ${ }^{4} \cdot$ 이영준 ${ }^{5} \cdot$ 유영준 $^{6} \cdot$ 박경실 $^{7} \cdot$ 민병진 ${ }^{7} \cdot$ 신용업 $^{8} \cdot$ 김정석 $^{9} \cdot$ 정훈 $^{*}$

( ${ }^{1}$ 목원대학교 스포츠산업학부, ${ }^{2}$ 세종대학교 체육학과, ${ }^{3}$ 한양대학교 의과대학 해부세포생물학교실, ${ }^{4}$ 건국대학 교 미래지식교육원, ${ }^{5}$ 숭실대학교 체육학과, ${ }^{6}$ 동덕여자대학교 모델학과, ${ }^{7}$ 경기대학교 레저·건강학과, ${ }^{8}$ 용인대 학교 격기지도학과, ${ }^{9}$ 용인대학교 유도학과)

본 연구는 비만과 노화가 동시에 유발된 흰쥐에서 12 주간의 트레드밀 운동과 L-arginine의 투여가 복부지방량, $\mathrm{GH}$, IGF- I , somatostatin, fibrinogen, PAI-1에 미치는 영향을 관찰하고 이를 개선하는데 더욱 효과적인 방법을 제시하는데 그 목적이 있다. 이를 위해 단독 처치 군과 복합 처치 군으로 나누어 실험하여 그 효과를 비교, 분석한 결과 다음과 같은 결론을 얻었다.

1. 복부지방량은 통제집단에 비해 모든 집단에서 유의하게 감소하였다 $(p<0.01)$.

2. $\mathrm{AG}+\mathrm{EX}, \mathrm{AG}+\mathrm{LA}+\mathrm{EX}$ 집단에서 통제집단에 비해 $\mathrm{GH}$ 의 혈중 농도가 유의하게 높게 나타났다 $(p<0.1)$.

3. $\mathrm{AG}+\mathrm{EX}, \mathrm{AG}+\mathrm{LA}+\mathrm{EX}$ 집단에서 통제집단에 비해 IGF-I 의 혈중 농도가 유의하게 증가하였다( $p<0.01)$. 